\title{
The Genetically Modified Organisms' Regime: A Playground for Multi-Level Administration and a Nightmare for Effective Judicial Protection?
}

\author{
Rui Lanceiro ${ }^{1, \star}$ and Mariolina Eliantonio ${ }^{2, * *}$ (D) \\ ${ }^{1}$ Faculty of Law, Universidade de Lisboa, Lisbon, Portugal and ${ }^{2}$ Faculty of Law, Maastricht University, Maastricht, Netherlands \\ Corresponding author: Mariolina Eliantonio, Email: m.eliantonio@maastrichtuniversity.nl
}

(Received 30 March 2021; accepted 11 April 2021)

\begin{abstract}
The European Union has a comprehensive legal framework in place for the authorization, traceability, and labelling of genetically modified organisms, the aim of which is to create a unified market while simultaneously ensuring that the placing on the market of the products concerned will not pose a risk to human or animal health or to the environment. This framework sets out complex, multi-level procedures which entail the cooperation and sharing of information between various national and European authorities. Filling a gap in the literature, this contribution focuses on the challenges to the system of judicial accountability that emerge in this particular system of multi-level administration. This Article shows that the problems posed by composite procedures in terms of access to justice and effective judicial protection can possibly be solved in light of the current rules concerning the division of labor between national and European courts and the applicable case law of the Court of Justice. As this Article will show, many more unsolved issues arise instead with respect to the compliance with the requirements of access to justice provided by the Aarhus Convention.
\end{abstract}

Keywords: Composite procedures; GMOs; effective judicial protection; Aarhus Convention; access to justice

\section{A. Introduction}

The European Union (EU) has a comprehensive legal framework in place for the authorization, traceability, and labeling of genetically modified organisms (GMOs), the aim of which is to create a unified market while simultaneously ensuring that the placing on the market of the products concerned will not pose a risk to human or animal health or to the environment. Historically, the main legislation regulating releases into the environment and placing on the market of GMOs in the European Community was Directive 90/220/ EEC, ${ }^{1}$ which established an approval process on a case-by-case assessment of the risks to human health and the environment. This horizontal directive complemented specialized

\footnotetext{
${ }^{*}$ Assistant Professor in European Administrative Law. Faculty of Law, University of Lisbon.

${ }^{* *}$ Professor of European and Comparative Administrative Law and Procedure. Department of Public Law, Faculty of Law, Maastricht University.

${ }^{1}$ Council Directive 90/220/EEC of 23 April 1990 on the Deliberate Release into the Environment of Genetically Modified Organisms, O.J. (L 117) 15.
}

(C) The Author(s) 2021. Published by Cambridge University Press on behalf of the German Law Journal. This is an Open Access article, distributed under the terms of the Creative Commons Attribution licence (http://creativecommons.org/licenses/by/4.0/), which permits unrestricted re-use, distribution, and reproduction in any medium, provided the original work is properly cited. 
vertical sectoral legislation as, for example, the Regulation on novel foods and novel food ingredients. ${ }^{2}$ Because of the political controversies over GMO safety and the role of the Commission in authorizing their use, ${ }^{3}$ the old framework was replaced by Directive 2001/18/EC on the deliberate release of genetically modified organisms ${ }^{4}$ and Regulation No. 1829/2003 on genetically modified food and feed, laying down the procedures for the authorization and supervision of genetically modified food and feed. ${ }^{5}$

These are the main legislative instruments in the field of GMOs still applicable today in the EU. On the one hand, Regulation (EC) No. 1829/2003 on genetically modified food and feed covers food, food ingredients, and feed containing, consisting of, or produced from GMOs. It also covers GMOs for other uses such as cultivation, if they are to be used as source material for the production of food and feed. On the other hand, Directive 2001/18/EC, on the deliberate release into the environment of genetically modified organisms, covers GMOs for uses other than food and feed, notably for cultivation or industrial uses. ${ }^{6}$ In this sense, the directive functions as the horizontal framework applicable to release of GMOs into the environment and the regulation as lex specialis regulating its use for food and feed, including its cultivation.

Both legislative acts set out complex, multi-level authorization procedures which entail the cooperation and sharing of information between various national and European authorities, and ensure that marketed products are not harmful for health or the environment. In view of this, a scientific risk assessment is at the heart of the procedure: Every authorization for placing a product on the market should be duly justified and the main ground for its reasoning should be scientific.

While these procedures have been extensively analyzed by the literature concerning science and scientific evidence in regulatory decision-making, ${ }^{7}$ technocratic governance in the

\footnotetext{
${ }^{2}$ Regulation (EC) 258/97 of the European Parliament and of the Council of 27 January 1997 Concerning Novel Foods and Novel Food Ingredients, O.J. (L 43) 1. This regulation, which established rules for authorizations and labelling of GMO derived food products and other novel foods, was later repealed by Regulation 2015/2283 of the European Parliament and of the Council of 25 November 2015 on Novel Foods, 2015 O.J. (L 327) 1.

${ }^{3}$ In June 1999, France and Greece, backed by Belgium, Denmark, and Luxembourg, called for a de facto moratorium on new GMO approval. They were later joined by Belgium and Austria, forming a minority of EU Member states that could block any vote on a new approval. The next year, in the Environment Council Meeting of June 1999, different groups of Member States made two declarations. With slightly different wording, they stated the intention of the Member States to block the authorization of GMOs in Council pending amendment of the legislation, see Declaration by the Danish, Greek, French, Italian, and Luxembourg Delegations Concerning the Suspension of New GMO Authorisations and Declaration by the Austrian, Belgian, Finnish, German, Netherlands, Spanish, and Swedish Delegations, published in European Commission Press Release C/99/ 203, 2194th Council Meeting - Environment - Luxembourg, 24/25 June 1999, https://ec.europa.eu/commission/presscorner/ detail/en/PRES_99_203. It was not until May 2004 that the European Commission put an end to this situation by authorizing imports of Bt-11 maize. See Maria Lee, EU Regulation of GMOs Law and Decision Making for a New Technology $2-$ 11 (2008); Sarah Lieberman \& Tim Gray, The So-Called "Moratorium" on the Licensing of New Genetically Modified (GM) Products by the European Union 1998-2004: A Study in Ambiguity, 15 ENVTL. POL. 592 (2006).

${ }^{4}$ Directive 2001/18, of the European Parliament and of the Council of 12 March 2001 on the Deliberate Release Into the Environment of Genetically Modified Organisms and Repealing Council Directive 90/220/EEC, 2001 O.J. (L 106) 1.

${ }^{5}$ Regulation (EC) No 1829/2003 of the European Parliament and of the Council of 22 September 2003 on Genetically Modified Food and Feed, 2003 O.J. (L 268) 1.

${ }^{6}$ It should be noted, for the sake of completeness, that the EU legal framework also includes Regulation 1830/2003, of the European Parliament and of the Council of 22 September 2003 Concerning the Traceability and Labelling of Genetically Modified Organisms and the Traceability of Food and Feed Products Produced from Genetically Modified Organisms and Amending Directive 2001/18, 2003 O.J. (L 268) 24 (EC); Directive 2009/41, of the European Parliament and of the Council of 6 May 2009 on the Contained Use of Genetically Modified Micro-Organisms, 2009 O.J. (L 125) 75 (EC); Regulation 1946/ 2003, of the European Parliament and of the Council of 15 July 2003 on Transboundary Movements of Genetically Modified Organisms, 2003 O.J. (L 287) 1 (EC). However, these two pieces of legislation will not be analyzed in this Article.

${ }^{7}$ See, e.g., Elizabeth Fisher, Framing Risk Regulation: A Critical Reflection, 4 Eur. J. Risk Reg. 125 (2013); Mihail Kritikos, Traditional Risk Analysis and Releases of GMOs into the European Union: Space for Non-Scientific Factors?, 34 EUR. L. REV. 405 (2009); Maria Lee, Beyond Safety? The Broadening Scope of Risk Regulation, 62 CURRENT LeGAL Probs. 242 (2009); Giulia Claudia Leonelli, GMO Risks, Food Security, Climate Change and the Entrenchment of Neo-Liberal Legal Narratives, 9 Transnat'l Legal Theory 302 (2013); Miguel Recuerda, Enrique Garcia, Fernando Botija, Pedro Peralta, Anselmo
} 
$\mathrm{EU},{ }^{8}$ and the applicability of the precautionary principle, ${ }^{9}$ the exemplary nature of these decision-making processes for the system of EU multi-level administration has, until now, remained very much in the background. This contribution focuses on the challenges to the system of judicial accountability that emerge in this particular system of multi-level administration.

Access to justice and judicial control of administrative decisions and processes is a particularly relevant topic that has become a growing concern of the Court of Justice of the EU in recent cases, especially in the context of Article 47 of the Charter of Fundamental Rights of the EU. ${ }^{10}$ Judicial accountability in multi-level administration has also been increasingly analyzed by scholars, who have tried to systematize the body of case law to understand its gaps and constitutional implications. ${ }^{11}$ Given the highly sensitive and contested nature of GMO regulation, ensuring access to justice is particularly important. This Article applies the discussion on access to justice and judicial protection for the first time to the area of GMOs, an exemplary-yet in some aspects peculiarfield of EU multi-level administrative governance.

Indeed, while the legal procedure applicable to the authorization of GMOs resembles, to some extent, other so-called "composite procedures", 12 it presents certain peculiarities in terms of access to justice because it is subject to the specific regime of the United Nations Economic Commission for Europe (UNECE) Convention on Access to Information, Public Participation in Decision-Making and Access to Justice in Environmental Matters, also known as the

Canellas, Alejandro Candeira, Lucia Ghisleri, Maria Martinez-Larranaga \& Arturo Anadon, Administrative Authorizations, Risk and Biotechnology, 4 EUR. Food \& FeEd L. ReV. 251 (2009).

${ }^{8}$ See, e.g., Estelle Brosset, The Prior Authorisation Procedure Adopted for the Deliberate Release into the Environment of Genetically Modified Organisms: The Complexities of Balancing Community and National Competences, 10 EuR. L.J. 555 (2004). On this point, see generally MARIA LeE, EU Regulation of GMOs (2008); Maria Weimer, Risk Regulation and Deliberation in EU Administrative Governance-GMO Regulation and Its Reform, 21 EUR. L.J. 622 (2015). See generally Maria Weimer \& Anniek De Ruijter, Regulating Risks In The European Union: The Co-Production of Expert AND EXeCuTive Power (2017).

${ }^{9}$ See, e.g., Joyce Tait, More Faust than Frankenstein: The European Debate About the Precautionary Principle and Risk Regulation for Genetically Modified Crops, 4 EUR. J. RISK REg. 175 (2001); Maria Weimer, Applying Precaution In EU Authorisation of Genetically Modified Products_Challenges and Suggestions for Reform, 16 EuR. L.J. 624 (2010); John S. Applegate, The Prometheus Principle: Using the Precautionary Principle to Harmonize the Regulation of Genetically Modified Organisms, 9 Ind. J. Global Legal Stud. 207 (2001); Giovanni Tagliabue, The Precautionary Principle: Its Misunderstandings and Misuses in Relation to "GMOs", 33 NEW BIOTECHNOLOGY 437 (2016). In general, see on the precautionary principle, Giulia Claudia Leonelli, Acknowledging the Centrality of the Precautionary Principle in Judicial Review of EU Risk Regulation: Why it Matters, 57 Common MKt. L. Rev. 1773 (2020).

${ }^{10}$ See, e.g., ECJ, Case C-219/17, Silvio Berlusconi \& Finanziaria d'investimento Fininvest SpA (Fininvest) v. Banca d'Italia and Istituto per la Vigilanza Sulle Assicurazioni (IVASS), ECLI:EU:C:2018:1023 (Dec. 19, 2018), http://curia.europa.eu/juris/ liste.jsf?num=C-219/17; ECJ, Case C-682/15, Berlioz Investment Fund SA v. Directeur de l'administration des contributions directes, ECLI:EU:C:2017:373 (May 16, 2017), http://curia.europa.eu/juris/liste.jsf?num=C-682/15.

${ }^{11}$ See Herwig C.H. Hofmann, Composite Decision Making Procedures in EU Administrative Law, in LEGAL CHALLENGES IN Eu Administrative Law: Towards an Integrated Administration 136-67 (Herwig H.C. Hofmann \& Alexander Türk eds., 2009); Mariolina Eliantonio, Judicial Review in an Integrated Administration: The Case of "Composite Procedures", 7 REV. Eur. Admin. L. 65 (2014); Filipe Brito Bastos, The Borelli Doctrine Revisited: Three Issues of Coherence in a Landmark Ruling for EU Administrative Justice, 8 Rev. Eur. AdmIn. L. 269 (2015); Filipe Brito Bastos, Derivative Illegality in European Composite Administrative Procedures, 55 Common MkT. L. Rev. 101 (2018); Joseba K. Fernández Gaztea, A Jurisdiction of Jurisdictions, 12 REV. EUR. ADMIN. L. 9 (2019). With regards to composite procedures involving agencies, see generally Miroslava Scholten \& Michiel Luchtmans, Law Enforcement by EU Authorities: Implications for Political AND JUdiCIAL ACCOUNTABILITY (2017). With regard to composite procedure involving data sharing activities, see Special Issue, 20 EUR. PUB. L. (2014). In relation to pharmaceuticals authorizations, see Sabrina Röttger-Wirtz \& Mariolina Eliantonio, From Integration to Exclusion: EU Composite Administration and Gaps in Judicial Accountability in the Authorisation of Pharmaceuticals, 10 EUR. J. RISK REG. 393 (2019).

${ }^{12}$ Namely procedures entailing the input of administrative actors from different jurisdictions, and in which the final decision, issued by a Member State or an EU authority, is based on procedures involving the more or less formalized input of the various participating authorities, as in the definition provided by Herwig C.H. Hofmann, Gerard C. Rowe \& AlEXANDER Türk, Administrative Law and Policy of the European Union 406 (2011). 
Aarhus Convention. ${ }^{13}$ This Convention recognizes certain procedural rights to the members of the public and imposes obligations to the authorities of its Parties in terms of administrative and judicial procedure as instruments to the protection of the environment. These rights are: i) A right to environmental information; ii) A right to participation in decision-making; and iii) A right of access to judicial review in environmental matters. Both the European Union and all of its Member States are parties to the Aarhus Convention. ${ }^{14}$

In this Article, we will, at the outset, examine how the Aarhus Convention is relevant for GMO regulation at national and EU level. Thereafter, we will, first, analyze all steps of the decision-making in the various marketing authorization decisions. The analysis will bring to the fore the extreme complexity of some of the procedures ${ }^{15}$ which is aimed at pre-empting political or judicial confrontation between diverging interest, providing incentives for consensus, or guaranteeing a near-veto power to the Commission or the Member States. Second, we will assess the judicial reviewability of each of these steps. In particular, the analysis will concern the questions of whether a specific step of the decision-making process constitutes a reviewable act-if not, whether that step will be reviewable together with a later stage of the decision-making process - and whether different categories of applicants will be granted standing. The analysis will be carried out both in as far as the national and the European levels of decision-making are concerned. Accordingly, the main focus of the Article is to explain the procedures in question, either centralized at the supranational level, as is the case of the one provided by the regulation, or mixed with national and supranational stages, as is the case of the directive, ${ }^{16}$ and provide an analysis of the judicial protection afforded to the several actors, identifying the underlying gaps in access to judicial review procedures. In order to do this analysis, we will look at Article 47 of the Charter as a particular benchmark to conclude if a gap in judicial protection takes place. ${ }^{17}$

This Article will show that the problems posed by composite procedures in terms of access to justice and effective judicial protection can possibly be solved in light of the current rules concerning the division of labor between national and European courts and the applicable case law of the Court of Justice, which is pointing towards an increasingly holistic system of judicial

\footnotetext{
${ }^{13}$ The Aarhus Convention was adopted on June 25, 1998 at the Fourth Ministerial Conference as part of the "Environment for Europe" process in the Danish city of Aarhus and entered into force on Oct. 30, 2001, after obtaining ratifications by sixteen of the signatory parties. In general, on the Convention and its innovative nature for the purposes of promoting "environmental democracy," see Esther Pozo Vera, The Aarhus Convention: A Tool for Environmental Democracy and Defending Consumers Rights on the Environment, 1 J. Eur. CONSUMER \& MKT. L. 53 (2011); Michel Prieur, La Convention d'Aarhus, Instrument Universel de la Démocratie Environnementale, Revue JuRIDIQUe De L'ENVIRONNEMENT 9 (1999).

${ }^{14}$ The European Community (EC) became a party to the Aarhus Convention on May 17, 2008, following its approval by Council Decision 2005/370 of 17 February 2005 on the Conclusion, on Behalf of the European Community, of the Convention on Access to Information, Public Participation in Decision-Making and Access to Justice in Environmental Matters, 2005 O.J. (124) 1 (EC). However, with the entry into force on Dec. 1, 2009 of the Treaty of Lisbon amending the Treaty on European Union and the Treaty Establishing the European Community, the duality between European Community and EU ended. The EU was recognized as a single legal personality which replaced the former EC, namely as a Party to the Aarhus Convention. See Consolidated Version of the Treaty on European Union art. 1(3), Oct. 26, 2012, 2012 O.J. (C 326) 13 [hereinafter TEU]; See also Treaty of Lisbon Amending Treaty on European Union and the Treaty Establishing the European Community art. 2(2)(a), Dec. 13, 2007, 2007 O.J. (C 306) 1 [hereinafter Treaty of Lisbon].

${ }^{15}$ See, on this point, for example, Weimer, supra note 8, at 37-40; Claudio Mereu, Schizophrenic Stakes of GMO Regulation In The European Union, 3 Eur. J. RIsK REg. 202 (2012); Maria Lee, Multi-Level Governance of GMOs in the EU: Ambiguity and Hierarchy, in The Regulation of GMOs: Comparative Approaches 2-5 (Michael Cardwell \& Luc Bodiguel eds., 2010). As for an analysis of the situation before 2001, see, for example Les Levidow, Susan Carr \& David Wield, Genetically Modified Crops in the European Union: Regulatory Conflicts as Precautionary Opportunities, 3 J. RISK RES. 189 (2000).

${ }^{16}$ The difference between the regimes also offers a possible explanation for the different choice of act used. A directive when regulating a procedure with national and supranational stages, where there is a significant participation of Member States, and a regulation when establishing a centralized procedure at the EU level.

${ }^{17}$ See further on Article 47 of the Charter and its relevance in the context of multi-level administration, Luis Arroyo Jiménez, Effective Judicial Protection and Mutual Recognition in the European Administrative Space, in this issue; and Emilie Chevalier \& Olivier Dubos, The Notion of "Transnationality" in Administrative Law: Taxonomy and Judicial Review, in this issue.
} 
review, entailing that one single court is competent for the review of the entirety of the decisionmaking process. As the Article will show, many more unsolved issues arise instead with respect to the compliance with the requirements of access to justice provided by the Aarhus Convention.

\section{B. The Aarhus Convention and GMO Regulation}

The relevance of the Aarhus Convention for the field of GMOs is apparent with respect to all three pillars of the Convention. First, the right of access to environmental information covers any information on the state of elements of the environment, such as biological diversity and its components, including GMOs. ${ }^{18}$ Second, the regime of public participation in decisions on specific activities, established in Article 6 of the Convention, is applicable to decisions on whether to permit the deliberate release of genetically modified organisms into the environment, within the framework of the national law of the States Party to the Convention, "to the extent feasible and appropriate."19 Third, and particularly relevant for the purposes of this Article, Article 9 of the Aarhus Convention guarantees the right of access to a review procedure before a court of law or another independent and impartial body established by law in case: i) The person considers that his or her request for environmental information has been ignored, wrongfully refused - whether in part or in full-inadequately answered, or otherwise not dealt with in accordance with the provisions of that article; or ii) the members of the public concerned who have a sufficient interest or who maintain impairment of a right, wish to challenge the substantive and procedural legality of any decision, act, or omission subject to the provisions of Article 6 of the Convention, which establishes the regime of public participation in decisions on specific activities. Both of these cases are applicable in the area of GMOs. In addition, pursuant to the same provision, each Party to the Aarhus Convention shall also ensure that, "where they meet the criteria, if any, laid down in its national law, members of the public have access to administrative or judicial procedures to challenge acts and omissions by private persons and public authorities which contravene provisions of its national law relating to the environment." 20

In the context of the EU's obligations as a Party to the Aarhus Convention, the EU adopted Regulation (EC) No. 1367/2006, of 6 September 2006, covering, amongst others, access to justice in environmental matters in relation to EU institutions and bodies. ${ }^{21}$

In particular, in its Article 10, the Aarhus Regulation institutes a procedure granting standing to non-governmental organizations (NGO) which meet the criteria set out in Article 11 to make a request for internal review to the EU institution or body that has adopted an administrative act under environmental law or, in case of an alleged administrative omission, should have adopted such an act. Under Article 12 of the Aarhus Regulation, the NGO that made the request "may institute proceedings before the Court of Justice in accordance with the relevant provisions of the Treaty" even in the absence of a response by the institution or body. ${ }^{22}$

\footnotetext{
${ }^{18}$ Aarhus Convention on Access to Information, Public Participation in Decision-Making and Access to Justice in Environmental Matters art. 2(3)(a), June 25, 1998, 2161 U.N.T.S. 447 [hereinafter Aarhus Convention].

${ }^{19}$ Aarhus Convention art. 6(11). It should be noted that, through Decision II/1 adopted at its second session-Almaty, May 25-27, 2005- the Meeting of the Parties to the Aarhus Convention adopted an amendment to the Aarhus Convention regarding genetically modified organisms, providing for early and effective information and public participation prior to making decisions on whether to permit the deliberate release into the environment and placing on the market of genetically modified organisms, thereby strengthening the current regime set out in Article 6(11) of the Convention. This amendment has, however, not yet come into force.

${ }^{20}$ Aarhus Convention art. 9(3).

${ }^{21}$ Regulation 1367/2006 of the European Parliament and of the Council of 6 September 2006 on the Application of the Provisions of the Aarhus Convention on Access to Information, Public Participation in Decision-Making and Access to Justice in Environmental Matters to Community Institutions and Bodies, 2006 O.J. (L 264) 13 [hereinafter Aarhus Regulation].

${ }^{22}$ It should be mentioned that, in response to the findings by the Aarhus Convention Compliance Committee of NonCompliance with Article 9(3) of the Aarhus Convention by the European Union, see Jeremy Wates (Secretary to the
} 
Regarding access to justice at the national level, and unlike other areas falling within the scope of the same provision, no specific measures were adopted by the EU to implement Article 9(2) of the Aarhus Convention with respect to GMO authorizations. ${ }^{23}$ Nonetheless, that fact does not imply that the Convention does not have any effect at national level. Indeed, Member States are both under a direct obligation of compliance to the Aarhus Convention, derived from international law and the principle of pacta sunt servanda, and an indirect obligation to comply with the same Convention, which stems from EU law. ${ }^{24}$ Member States must ensure compliance with commitments arising from an agreement, mixed or not, concluded by the EU institutions, in order to fulfil, within the EU system, their obligations in relation to the Union, which has assumed responsibility for the due performance of the agreement, ${ }^{25}$ under Article 216(2) of the Treaty on the Functioning of the European Union (TFEU) ${ }^{26}$ and as a consequence of the principle of sincere cooperation between the Union and the Member States. ${ }^{27}$ As a consequence, Article 9(2) of the Convention remains applicable to Member States when they act within the scope of application of Directive 2001/18/EC.

Aarhus Convention), Communication to the Aarhus Convention's Compliance Committee, Communication ACCC/C/2008/32 (Dec. 1, 2008) https://unece.org/DAM/env/pp/compliance/C2008-32/communication/Communication.pdf, the Commission has proposed an amendment to the Aarhus Regulation-Proposal for a Regulation of the European Parliament and of the Council, on Amending Regulation (EC) No 1367/2006 of the European Parliament and of the Council of 6 September 2006 on the Application of the Provisions of the Aarhus Convention on Access to Information, Public Participation in DecisionMaking and Access to Justice in Environmental Matters to Community Institutions and Bodies, COM (2020) 642 final (Oct. 14, 2020) [hereinafter Commission Proposal of Oct. 14, 2020]. For an overview of the struggle between the EU and the Compliance Committee over Communication ACCC/C/2008/32, see Rui Lanceiro, The Review of Compliance with the Aarhus Convention of the European Union, in Global Administrative Law \& EU Administrative Law Relationships, Legal Issues and Comparison 359 (Edoardo Chiti \& Bernardo Giorgio Mattarella eds., 2011); Rui Lanceiro, Access to Justice in Environmental Matters in the EU: Cooperation and Tension Between the Aarhus Compliance Committee and the Court of Justice of the EU, in THE Role OF COURTS IN CONTEMPORARY Legal Orders 483 (Martin Belov ed., 2019); Matthijs van Wolferen \& Mariolina Eliantonio, Access to Justice in Environmental Matters in the EU: The EU's Difficult Road Towards Non-Compliance with the Aarhus Convention, in RESEARCH HANDBOOK ON EU ENVIRONMENTAL LAW (Marjan Peeters \& Mariolina Eliantonio eds., 2020). On the new proposal of the Commission amending the Aarhus Regulation, see Ioanna Hadjiyianni, Access to Justice in Environmental Matters in the EU Legal Order-Too Little Too Late?, EUR. L. BlOG (Apr. 11, 2020), https://europeanlawblog.eu/2020/11/04/access-to-justice-in-environmental-matters-in-the-eulegal-order-too-little-too-late/; Anne Friel, The Aarhus Regulation Amendment: Cause for Cautious Celebration, CLIENT EARTH (Nov. 6, 2020), https://www.clientearth.org/projects/access-to-justice-for-a-greener-europe/updates/the-aarhusregulation-amendment-cause-for-cautious-celebration/; Tiina Paloniitty and Päivi Leino-Sandberg, Watering Down the Aarhus Regulation - Time to Deliver an 'Adequate and Effective Remedy', Eur. L. BLog (March 11, 2021), https:// europeanlawblog.eu/2021/03/11/watering-down-the-aarhus-regulation-time-to-deliver-an-adequate-and-effective-remedy/.

${ }^{23}$ The main instrument to bring Member States legislation in line with Article 9(2) of the Convention is Directive 2003/35 of the European Parliament and of the Council of 26 May 2003 Providing for Public Participation in Respect of the Drawing Up of Certain Plans and Programmes Relating to the Environment and Amending with Regard to Public Participation and Access to Justice Council Directives 85/337/EEC and 96/61/EC-Statement by the Commission, 2003 O.J. (L 156) 17 (EC). This instrument is not relevant for GMO regulation, as it does not bring any modifications to Directive 2001/18, supra note 4 .

${ }^{24}$ See Lanceiro, The Review of Compliance with the Aarhus Convention of the European Union, supra note 22. See also Lanceiro, Access to Justice in Environmental Matters in the EU: Cooperation and Tension Between the Aarhus Compliance Committee and the Court of Justice of the EU, supra note 22.

${ }^{25}$ See, to that effect, ECJ, Case C-12/86, Meryem Demirel v. Stadt Schwäbisch Gmünd, ECLI:EU:C:1987:400 (Sept. 30, 1987), para. 11, https://eur-lex.europa.eu/legal-content/EN/TXT/?uri=CELEX\%3A61986CJ0012; ECJ, Case C-13/00, Comm'n v. Ireland, ECLI:EU:C:2002:184 (Mar. 19, 2002), para. 15, https:/eur-lex.europa.eu/legal-content/EN/TXT/?uri=CELEX:62000CJ0013_SUM; Opinion of Advocate General Kokott, Case C-239/03, European Comm'n v. Hungary (Mar. 5, 2020); ECJ, Case C-239/03, Comm'n v. France, ECLI:EU:C:2004:598 (Oct. 7, 2004), para. 26, http://curia.europa.eu/juris/liste.jsf?language=en\&num=C-239/03.

${ }^{26}$ See, to this effect, ECJ, Case C-61/94, Comm'n v. Germany, ECLI:EU:C:1996:313 (Sept. 10, 1996), para. 52, https://eur-lex. europa.eu/legal-content/HR/TXT/?uri=CELEX:61994CJ0061; ECJ, Case C-311/04, Algemene Scheeps Agentuur Dordrecht BV v. Inspecteur der Belastingdienst Douanedistrict Rotterdam, ECLI:EU:C:2006:23 (Jan 12, 2006), para. 25, http://curia. europa.eu/juris/liste.jsf?language $=$ en $\&$ num $=$ C-311/04; ECJ, Case C-308/06, Intertanko and Others v. Secretary of State for Transport, ECLI:EU:C:2008:312 (June 3, 2008), para. 42, http://curia.europa.eu/juris/liste.jsf?language=en\&num=C$308 / 06$

${ }^{27} \mathrm{TEU}$, art. $4(3)$. 


\section{GMOs Decision-Making Procedures in Regulation (EC) No. 1829/2003 and Access to Justice}

\section{The Authorization Procedure Under Regulation (EC) No. 1829/2003: A Supranational Procedure with a "National Touch"}

Regulation (EC) No. 1829/2003 established the specific authorizing procedures for the placing on the market of genetically modified food, food ingredients, and feed containing, consisting of, or produced from GMOs. ${ }^{28}$ There is, therefore, a difference in scope between this regulation and the directive. The use of GMOs in food or feed without cultivation or with cultivation in the EU falls under the authorization procedure established in the regulation. The procedure provided for in the directive is currently only applicable if GMOs do not have food or feed destinations, notably for cultivation. ${ }^{29}$

The decision-making procedure established in the regulation begins with the submission of an application for authorization to the competent authorities of a Member State, which immediately inform the European Food Safety Authority (EFSA), an EU agency. ${ }^{30}$ The national authorities forward the application to the EFSA, which is the authority responsible for risk assessment in the food sector and the issuing of an opinion on the basis of that assessment. In the context of its evaluation, the EFSA shall verify the information and documentation submitted and forward it to the European Union reference laboratory ${ }^{31}$ to test and validate the method of detection and identification proposed by the applicant. The EFSA may, or, in specific cases, ${ }^{32}$ must ask the appropriate food or feed assessment body of a Member State to carry out a food or feed safety assessment or ask a competent national authority designated in accordance with Directive 2001/ $18 /$ EC to carry out an environmental risk assessment. ${ }^{33}$ During the evaluation of requests for the placing on the market of products consisting of or containing GMOs, the EFSA also consults the national competent authorities, which may issue their opinions. ${ }^{34}$ This complexity can be explained by the fact that the authorization procedure established in the regulation may allow the use of GMOs not only for food and feed-where human or animal risks occupy a central stage-but also for cultivation-where environmental risk must also be taken into consideration. After concluding its evaluation, the EFSA sends its opinion to the Member States, the Commission, and the applicant including a reasoned report describing its assessment of the food and the information on which the opinion is based, including the opinions of the national competent authorities. ${ }^{35}$ The EFSA also makes its opinion public, after deletion of confidential information. The public may make comments to the Commission within thirty days from such publication. ${ }^{36}$

On receipt of the EFSA's opinion and on the basis thereof, the Commission shall draw up and submit to the relevant "comitology" 37 committee-which is the Standing Committee on Plants,

\footnotetext{
${ }^{28}$ For an analysis of this procedure, see Andrea KeESSEN, European Administrative Decisions-How the EU Regulates Products on the Internal Market 40 (2009).

${ }^{29} \mathrm{On}$ the relation between the two regimes, ECJ, Case T-240/10, Hungary v. Comm'n, ECLI:EU:T:2013:645 (Dec. 13, 2013), paras. 1-14, https://eur-lex.europa.eu/legal-content/EN/TXT/PDF/?uri=CELEX:62010TJ0240 (regarding Amflora genetically modified potato). See also Keessen, supra note 28 , at 36.

${ }^{30}$ Regulation 1829/2003, supra note 5, at arts. 5(2) \& 17(2).

${ }^{31}$ As defined in art. 32 of the regulation. See id. at art. 32.

${ }^{32}$ If the application concerns GMOs to be used as seeds or other plant-propagating material, the regulation establishes the need for EFSA to ask a national competent authority to carry out the environmental risk assessment. See id. at arts. 6(3) \& $18(3)$.

${ }^{33} I d$.

${ }^{34} I d$. at arts. $6(4) \& 18(4)$.

${ }^{35} I d$. at arts. $6(6) \& 18(6)$.

${ }^{36} I d$. at arts. 6(7) \& 18(7).

${ }^{37}$ The term "comitology" refers to the set of procedures through which the European Commission exercises the implementing powers conferred on it by the EU legislator, with the assistance of committees of representatives from EU countries, under Article 291(2) and (3) of the Consolidated Version of the Treaty on the Functioning of the European Union, May 9, 2008, 2008
} 
Animals, Food, and Feed (PAFF Committee), ${ }^{38}$ specifically the Genetically Modified Food and Feed and Environmental Risk Section ${ }^{39}$ — a draft decision accepting or rejecting the request. The draft decision must take into account the opinion of the EFSA, any relevant provisions of EU law, and other legitimate factors relevant to the matter under consideration, where one may include comments by the public or opinions of Member States. Where the draft decision is not in accordance with EFSA's opinion, the Commission must state the reasons for the differences. ${ }^{40}$ The decision shall be taken in accordance with the examination committee procedure foreseen in Articles 7(3) and 19(3) of the regulation. ${ }^{41}$ This means that the PAFF Committee may approve or reject the proposed decision by a qualified majority vote, which is binding to the Commission. If the Committee rejects the draft or if there is no qualified majority either for or against the proposed act, the Commission must submit a new, amended version to the PAFF Committee or to the Appeal Committee. If the Appeal Committee gives no opinion, the Commission "may" adopt the decision, which takes the form of an implementing decision addressed to the applicant. ${ }^{42}$

This is a particular decision-making procedure. While it is mostly centralized at the EU level, at the EFSA, which analyzes the application, and the Commission, which drafts the decision, national administrations also play an important role. ${ }^{43}$ They are present at the beginning of the procedure, receiving the applications, but also participate throughout the analysis of the application by the EFSA. ${ }^{44}$ During this stage, besides being able to request the applicant to supplement the particulars accompanying the application, the national authorities participate, while the EFSA is preparing its opinion: i) At the request of the EFSA itself, by preparing a food safety assessment or an environmental risk assessment, and ii) by issuing their own opinion. ${ }^{45}$ While in the first case,

O.J. (C 115) 47 [hereinafter TFEU]. Such comitology committees give an opinion on implementing acts proposed by the Commission. See Regulation 182/2011 of the European Parliament and of the Council of 16 February 2011 Laying Down the Rules and General Principles Concerning Mechanisms for Control by Member States of the Commission's Exercise of Implementing Powers, 2011 O.J. (L 55) 13 (EC) [hereinafter Comitology Regulation]. The Commission presented a proposal to amend the Comitology Regulation precisely because of problems identified in the GMO area. See Proposal for a Regulation of the European Parliament and of the Council Amending Regulation (EU) No 182/2011 Laying Down the Rules and General Principles Concerning Mechanisms for Control by Member States of the Commission's Exercise of Implementing Powers, COM (2017) 85 final (Feb. 14, 2017). The amendment is still under consideration. See, e.g., Ana Mar Fernández Pasarín, Renaud Dehousse \& Joan Pere Plaza, Comitology: The Strength of Dissent, J. Eur. InTEgration 1 (2020); Ton Van Den Brink, Danger! Glyphosate May Expose Weaknesses in Institutional Systems: EU Legislation and Comitology in the Face of a Controversial Reauthorisation, 11 EUR. J. RISK REG. 436 (2020); Jens Blom-Hansen \& Gijs Jan Brandsma, The EU Comitology System: Intergovernmental Bargaining and Deliberative Supranationalism, 47 J. COMmON MKT. STUD. 719 (2009); Chrisitan Joerges \& Jurgen Neyer, Transforming Strategic Interaction into Deliberative Problem-Solving: European Comitology in the Foodstuffs Sector, 4 J. EUR. PUB. POL'Y 609 (1997).

${ }^{38}$ The PAFF Committee was created by Article 58 of Commission Regulation 178/2002, 2002 O.J. (L 31) 1 (EC) as amended by Regulation 652/2014, art. 48, 2014 O.J. (L 189) 1.

${ }^{39}$ The Standing Committee on Plants, Animals, Food and Feed is divided into fourteen different sections.

${ }^{40}$ Commission Regulation 1829/2003, supra note 5, at arts. 7(1) \& 19(1).

${ }^{41}$ To the extent that Article 35(2) of the regulation refers to Decision 1999/468, art. 5, 1999 O.J. (L 184) 23 (EC) [hereinafter Comitology Decision II], which was repealed, it must be understood to refer to the examination procedure, which is in Article 5 of the Comitology Regulation, and it must be considered that the basic act provides that, in the absence of an opinion, the Commission may not adopt the draft implementing act. See Comitology Regulation, supra note 37, at art. 5(4), para. 2(b), ex vi art. 13(1)(c).

${ }^{42}$ Over the last years, Member States' votes in the PAFF Committee and in the Appeal Committee on genetically modified food and feed have systematically been "no opinion" outcomes-no qualified majority either in favor or against. As a consequence, the final decision on authorization has been left to the Commission, which is required by the GMO legal framework to adopt a decision.

${ }^{43}$ The need for this close cooperation between EFSA and the national administrations, namely in the environmental risk assessment, may be a consequence of the structure of EFSA. Its management board has fifteen members who do not represent any Member State. Besides a representative of the Commission, the Council appoints the other fourteen members after consulting the European Parliament from a shortlist drawn up by the Commission following an open call for expressions of interest. In addition, the EFSA's Scientific Panels of experts who are responsible for the bulk of EFSA's scientific assessment work do not represent any Member State.

${ }^{44}$ Commission Regulation 1829/2003, supra note 5, at arts. 5(2) \& 17(2).

${ }^{45} \mathrm{Id}$. at arts. 6(2), 18(2), 6(3)(b-c), 18(3)(b-c), 6(4), 18(4). 
the national administration is acting as part of the EU administration, aiding the EFSA, in the second case, it is issuing its opinion, as administration of a Member State, representing their own national interest. The comitology procedure also guarantees Member States' participation in the decision-making.

The table below schematizes the various steps of the decision-making process and the relevant institutional actors.

Table 1. Steps of the decision-making process established by Regulation No. 1829/2003

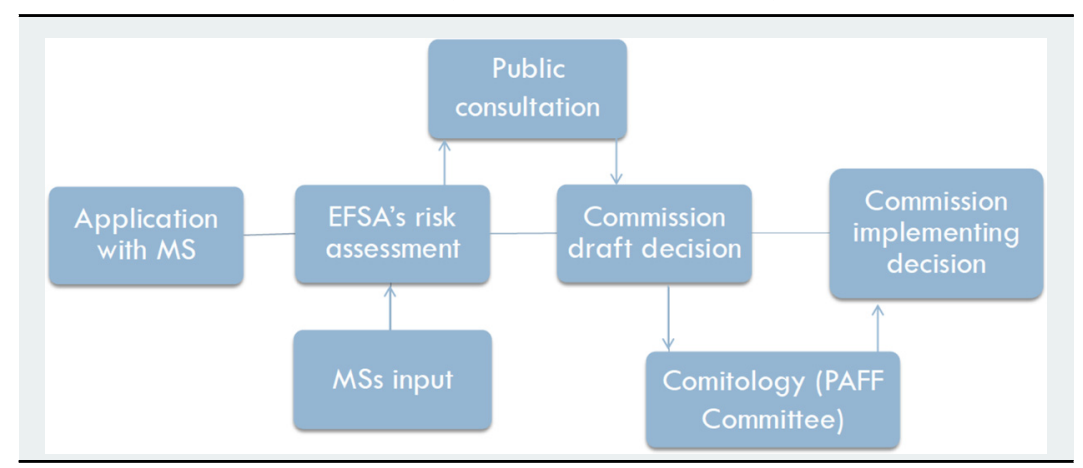

\section{The Gaps of Judicial Protection: The Possible Applicability of the Berlusconi Ruling and the Limitations of the Aarhus Regulation}

Several sets of questions relating to access to justice arise with respect to the procedure discussed in the section above.

The first is in relation to the judicial control of the acts and opinions of the competent national authorities. As stated previously, national authorities participate in the analysis of the application by the EFSA, both aiding the Authority and providing their opinions. In this context, how can the-preliminary-activity of the national administrations be judicially controlled? It seems that, in any of these two cases, the Oleificio Borelli doctrine ${ }^{46}$ does not apply ${ }^{47}$ because national administrations are only issuing non-binding opinions to be taken into consideration by the EFSA when issuing its own opinion, a condition which, according to the case law of the Court of Justice, seems to exclude the autonomous reviewability before the national courts of national authorities preparatory actions in the context of composite decision-making processes. ${ }^{48}$

Should these national actions and opinions then be controlled as part of the procedure leading to the EFSA's risk assessment and opinion? This question leads us to the second set of problems, regarding the reviewability of the EFSA's risk assessment and opinion, which can only be indirectly challenged. As it is not an act with legally binding external effects, it cannot be reviewed directly by the CJEU under Article 263 TFEU. The only available remedy is the administrative review procedure established in Article 36 of the regulation. This procedure allows the review by the Commission of any decision taken under, or failure to exercise, the powers vested in the EFSA by Regulation (EC) No. 1829/2003. The review can be initiated by the Commission itself, in response to a request from a Member State or from any person directly and individually

\footnotetext{
${ }^{46}$ ECJ, Case C-97/91, Oleificio Borelli S.p.A. v. Comm'n of the European Cmtys., ECLI:EU:C:1992:491 (Dec. 3, 1992), http:// curia.europa.eu/juris/liste.jsf?language $=$ en \&num $=c-97 / 91$.

${ }^{47}$ See on this point, Filipe Brito Bastos, The Borelli Doctrine Revisited: Three Issues of Coherence in a Landmark Ruling for EU Administrative Justice, 8 REv. EUR. AdMIN. L. 269 (2015).

${ }^{48}$ See Röttger-Wirtz \& Eliantonio, supra note 11 for a similar conclusion with respect to national preparatory activities in the context of marketing authorization procedures for pharmaceuticals.
} 
concerned-which includes the applicant but, if interpreted narrowly, excludes NGOs. The Commission has the power to require, if appropriate, the Authority to withdraw its decision or to remedy its failure to act. The decision of the Commission can be brought before the CJEU through an action for annulment of the decision. While this administrative review system provides for a mechanism to control EFSA's actions and omissions, it is doubtful that, lacking an explicit legislative provision to this effect, it might encompass also the actions of the national authorities.

As a consequence, the only available avenue which seems to remain open is the judicial review of the final Commission Implementing Decision rejecting the application for the authorization or granting the authorization itself. With respect to the question of the reviewability of EFSA's opinion, it seems rather straightforward, on the basis of the Court's case law, ${ }^{49}$ that a challenge against the final Commission decision will lead to the indirect review of the underlying EFSA's opinion.

The matter is much less straightforward with respect to the actions and opinions of the national authorities because these are acts issued by bodies which do not belong to the EU administration and whose control does not, in principle, fall within the jurisdiction of the Court of Justice. With respect to those, given the inapplicability of the Borelli doctrine because of the presence of a margin of discretion by all EU authorities involved, one might consider whether the Berlusconi case law might be applied..$^{50}$ In this ruling, the Court concluded that, when national preparatory measures are not binding upon EU authorities in a composite procedure, it falls to the CJEU not only to rule on the legality of a final decision adopted by the EU institution, but also to examine any defects vitiating the preparatory acts or the proposals of the national competent authorities that would be such as to affect the validity of that final decision. This would mean that the Court of Justice would be able to review the entirety of the decision-making process, including the opinions and other acts of the national competent authorities. While this holistic system of judicial review does ensure, as such, that all steps of the decision-making process leading to the final Commission decision are controlled by one single judicial instance, all issues pointed out in earlier writings with respect to the Berlusconi solution are equally relevant in this case. In particular, it is not clear whether only irregularities under EU law or also potential irregularities under national law fall within the jurisdiction of the CJEU as a consequence of the Berlusconi ruling. ${ }^{51}$ While a review limited to EU law related irregularities would leave national preparatory measures immune from judicial control with respect to possible violations of national law, the opposite solution will entail the possibility for the CJEU to consider and assess national law, a task which the Court seems to both be ill suited to conduct, not least in light of its limited fact-finding power, ${ }^{52}$ and prone to endanger the very autonomy of EU law. ${ }^{53}$

Furthermore, while the Commission's Implementing Decision approving or rejecting an application does certainly constitute a reviewable act in an annulment action, issues with standing arise with respect to third parties or organizations wishing to challenge, in particular, an approval decision.

\footnotetext{
${ }^{49}$ ECJ, Case T-326/99, Fern Olivieri v. Comm'n and EMEA, ECLI:EU:T:2003:351 (Dec. 18, 2003) http://curia.europa.eu/ juris/liste.jsf?language $=$ en\&num $=\mathrm{T}-326 / 99$.

${ }^{50}$ Silvio Berlusconi and Finanziaria d'investimento Fininvest SpA, Case C-219/17.

${ }^{51}$ See on this point, Paul Dermine and Mariolina Eliantonio, Case Note: CJEU (Grand Chamber), Judgment of Dec. 19, 2018, C-219/17, Fininvest v. IVASS, 12 Rev. Eur. Admin. L. 250-51 (2019); Filipe Brito Bastos, Derivative Illegality in European Composite Administrative Procedures, 55 Common MKT. L. Rev. 101, 126 (2018).

${ }^{52}$ See further on this Simona Demková, The Grand Chamber's Take on Composite Procedures Under the Single Supervisory Mechanism: Comments on Judgment of 27 June 2018, C-219/17 Silvio Berlusconi v. Finanziaria d'investimento Fininvest SpA (Fininvest) v. Banca d'Italia and others, EU:C:2018:502, 12 REv. EUR. ADMIN. L. 209 (2019). On the question of the treatment of national law before the CJEU, see in general, Miro Prek \& Silvère Lefèvre, The EU Courts as "National Courts"-National Law in the EU Judicial Process, 54 Common MKT. L. Rev. 369 (2017).

${ }^{53}$ As Brito Bastos notes, "Like a sort of administrative Trojan horse, those national preparatory acts would carry the violation of national law into the EU level, leading to the final EU decision being invalid on grounds of national law, and therefore breaking the autonomy of the EU legal order from within." Filipe Brito Bastos, An Administrative Crack in the EU's Rule of Law: Composite Decision-Making and Nonjusticiable National Law, 16 EUR. CONST. L. REV. 78 (2020).
} 
While the possibility to challenge that decision is indeed open to the applicant, as the addressee of the decision itself, problems may emerge for competitors. As the Commission's Implementing Decision is addressed to an individual applicant, it does not qualify as a regulatory act for the purposes of Article 263(4) TFEU, as it cannot be regarded as an act of general application. ${ }^{54}$ As a consequence, challenges against it cannot be admitted through the more relaxed standing conditions introduced for these kinds of acts by the Lisbon Treaty, entailing the need to prove merely direct concern to be granted standing in a direct action. Instead, applicants need to prove not only direct but also individual concern, a requirement which can prove to be very burdensome for private applicants under the Plaumann case-law. The CJEU has laid down its interpretation of this expression in the '60s in the Plaumann case, ${ }^{55}$ in which the Court ruled that:

[P] ersons other than those to whom a decision is addressed may only claim to be individually concerned if that decision affects them by reason of certain attributes which are peculiar to them or by reason of circumstances in which they are differentiated from all other persons, and by virtue of these factors distinguishes them individually just as in the case of the person addressed.

Furthermore, the Court has held consistently that the threshold of individual concern cannot be considered to be met in situations concerning "a commercial activity which may at any time be practiced by any person." ${ }^{26}$

In the specific case of NGOs, as previously stated, the Aarhus Convention is applicable, protecting access to justice in environmental matters. In this context, Article 10(1) of the Aarhus Regulation provides that any NGO which meets the criteria set out in its Article $11(1)^{57}$ is entitled to make a request for internal review to the EU institution or body that has adopted an "administrative act" under environmental law or, in case of an alleged administrative omission, ${ }^{58}$ should have adopted such an act. ${ }^{59}$ "Administrative act" is defined by Article 2(1)(g) of the Aarhus Regulation as "any measure of individual scope under environmental law, taken by a Community institution or body, and having legally binding and external effects." ${ }^{60}$ With respect to this notion in the area of Regulation (EC) No. 1829/2003, no problems arise for NGOs to access the internal review procedure, as the act they wish to have reviewed is, as mentioned above, a

\footnotetext{
${ }^{54}$ The CJEU, in the Inuit case, has defined a regulatory act under Article 263(4) TFEU as a "non-legislative act of general application.” See ECJ, Case C-583/11 P, Inuit Tapiriit Kanatami and Others v. European Comm’n, ECLI:EU:C:2013:625 (Oct 3, 2013), http://curia.europa.eu/juris/liste.jsf?num=C-583/11.

${ }^{55}$ See ECJ, Case 25/62, Plaumann \& Co. v. Comm'n of the European Econ. Cmty., ECLI:EU:C:1963:17 (July 15, 1963), http://curia.europa.eu/juris/liste.jsf?language=en\&jur=C,T,F\&num=25-62.

${ }^{56}$ See, e.g., ECJ, Case C-386/96 P, Société Louis Dreyfus \& Cie v. Comm'n of the European Cmtys., ECLI:EU:C:1998:193 (May 5, 1998), para. 43, http://curia.europa.eu/juris/liste.jsf?language=en\&num=C-386/96. See also ECJ, Case T-16/04, Arcelor SA v. Parliament and Council, ECLI:EU:T:2010:54 (Mar. 2, 2010), paras. 106-107, http://curia.europa.eu/juris/ liste.jsf?language $=$ en\&num $=\mathrm{T}-16 / 04$ (the General Court found that the applicant had failed to show "individual" concern, as it could not show it was part of a "closed group"-even if the applicant was one of a total of fifteen pig iron/steel producers operating on the relevant market).

${ }^{57}$ It must be an NGO that is "an independent non-profit-making legal person in accordance with a Member State's national law or practice," "has the primary stated objective of promoting environmental protection in the context of environmental law," or "has existed for more than two years and is actively pursuing the objective referred to."Finally, the subject matter in respect of which the request for internal review is made is covered by its objective and activities. Under Article 11(2) of the regulation, the Commission adopted provisions to ensure transparent and consistent application of those criteria, namely Commission Decision 2008/50 of 13 December 2007 Laying Down Detailed Rules for the Application of Regulation (EC) No. 1367/2006 of the European Parliament and of the Council on the Aarhus Convention as Regards Requests for the Internal Review of Administrative Acts, 2008 O.J. (L 13) 24 (EC).

58“Administrative omission" is defined by Article 2(1)(h) of the Aarhus Regulation as "any failure of a Community institution or body to adopt an administrative act as defined in (g).” Aarhus Regulation, supra note 21, at art. 2(1)(h).

${ }^{59} I d$. at art. $10(1)$, sub. para. 1.

${ }^{60} I d$. at art. 2(1)(g).
} 
Commission Implementing Decision with a named addressee, hence undisputedly an administrative act for the purposes of the Aarhus Regulation. ${ }^{61}$

Second, for the act to be reviewable in an internal review procedure, it must be taken "under environmental law" for the purposes of the Aarhus Regulation. The interpretation of this term has been settled by the CJEU in the TestBioTech case (T-33/16), ${ }^{62}$ in which the General Court recognized that an authorization decision to place a GMO on the market constitutes an act adopted under environmental law within the meaning of Article 2(1)(f) of the Aarhus Regulation. ${ }^{63}$ In their request for internal review, the NGO had pointed to a lack of guidance by the EFSA concerning the health impact of genetically modified crops with significantly altered nutritional content. The Commissioner for Health and Food Safety had refused the request for review on the ground that the complaints did not fall within the scope of the definition of acts that can be challenged under Article 10 of the Aarhus Regulation that need to be adopted "under environmental law." The Commissioner found, in essence, that environmental concerns and public health concerns were conceptually and legally distinct, hence the aspects relating to the health assessment of genetically modified food and feed could not be examined within the framework of Article 10 because they were not concerned with environmental risk assessment. The Court concluded that:

[E]nvironmental law, within the meaning of Regulation No. 1367/2006, covers . . any provision of EU legislation, concerning the regulation of genetically modified organisms, that has the objective of dealing with a risk to human or animal health, that originates in those genetically modified organisms or in environmental factors that may have effects on those organisms when they are cultivated or bred in the natural environment. ${ }^{64}$

By rejecting a narrow interpretation of the concept of act adopted "under environmental law," in this case, the General Court adopted a position that was favorable to broaden the possibility of NGOs to request an internal review in GMO-related cases.

The Aarhus Regulation also provides that NGOs whose requests for internal review have been unsuccessful may, in accordance with Article 12 of the Aarhus Regulation, read in conjunction with Article 10 thereof, institute proceedings before the CJEU "in accordance with the relevant provisions of the Treaty." 65 In that case, the NGO may ask the CJEU to review-on grounds of

\footnotetext{
${ }^{61}$ It is worth mentioning that this restrictive definition of administrative act, while not problematic for GMO authorization, has been considered too restrictive to comply with the Aarhus Convention by the Aarhus Convention Compliance Committee. The proposed amendment to the Aarhus Regulation that is under discussion adopts a broader definition of "administrative act." See Commission Proposal of Oct. 14, 2020, supra note 22.

${ }^{62}$ ECJ, Case T-33/16, TestBioTech eV v. European Comm'n, ECLI:EU:T:2018:135 (Mar. 14, 2018), para. 69, http://curia. europa.eu/juris/liste.jsf?num=T-33/16.

${ }^{63}$ This case concerns an action for annulment of a letter from the Commissioner for Health and Food Safety of 16 November 2015 Rejecting an Application for Internal Review, Based on Article 10 of the Aarhus Regulation, of Implementing Decisions Authorising the Placing on the Market of the Genetically Modified Soybeans MON 87769, MON 87705, and MON 305423.

${ }^{64}$ TestBioTech eV, Case T-33/16 at para. 69. See also ECJ, Case T-9/19, ClientEarth v. European Investment Bank, ECLI:EU: $\mathrm{T}: 2021: 42$ (January 27, 2021), https://curia.europa.eu/juris/liste.jsf?lgrec $=$ fr\&td=\%3BALL\&language $=$ en \&num $=\mathrm{T}-9 / 19 \&$ jur $=\mathrm{T}$ (the Court once gain rejected a narrow interpretation of the concept of act adopted "under environmental law"). See Rui Lanceiro, Analysis: “A step in the direction of broadening access to environmental justice: ClientEarth $v$ EIB", EU LAW LIVE (February 26, 2021), https://eulawlive.com/analysis-a-step-in-the-direction-of-broadening-access-toenvironmental-justice-clientearth-v-eib-by-rui-tavares-lanceiro/.

${ }^{65} \mathrm{TFEU}$, arts. 263, 264. The first case whereby applicant NGOs have instituted proceedings for annulment of the reply sent to them by the Commission under Title IV of the Aarhus Regulation was, ECJ, Case T-338/08, Stichting Natuur en Milieu and Pesticide Action Network Europe v. Comm'n, ECLI:EU:T:2012:300 (June 14, 2012), http://curia.europa.eu/juris/liste.jsf? num=T-338/08. The General Court decided in favour of the NGOs, but there was an appeal to the Court of Justice. The Court, in ECJ, Joined Cases C-404 \& 405/12P, Council of the European Union and European Comm'n v. Stichting Natuur en Milieu and Pesticide Action Network Europe, ECLI:EU:C:2015:5, (Jan. 13, 2015), https://curia.europa.eu/juris/ liste.jsf?num $=\mathrm{C}-404 / 12$, reversed the judgment of the General Court.
} 
lack of competence, infringement of an essential procedural requirement, infringement of the Treaties, or of any rule of law relating to their application, or misuse of powers - the decision rejecting the request for internal review. While no issues of standing arise in such case, as the latter decision is addressed to the NGO, the scope of the review of the Court will be limited to the written reply under the Article 10 procedure. Despite the fact that the Compliance Committee, which is the body in charge of overseeing the compliance of the parties with the Aarhus Convention, clarified that-in order for the EU to comply with the Convention, the review of the CJEU should extend also to the substance of the initial administrative act for which an administrative review procedure had been sought, ${ }^{66}$ the Court interpreted Article 12 of the Aarhus Regulation in a restrictive way.

In another TestBioTech case (T-177/13) both the General Court ${ }^{67}$ and the Court of Justice ${ }^{68}$ endorsed a restrictive interpretation of Article 12, not extending to a review of the initial act, and held that judicial proceedings:

$[\mathrm{C}]$ annot be founded on new grounds or on evidence not appearing in the request for review, as otherwise the requirement, in Article 10(1) of Regulation No 1367/2006, relating to the statement of grounds for such a request would be made redundant and the object of the procedure initiated by the request would be altered. ${ }^{69}$

The General Court confirmed this approach in the ClientEarth case (T-108/17), ${ }^{70}$ adding clarity to its application in practice. The CJEU reaffirmed that the Article 12 procedure can result in the annulment of the internal review decision, and not in the underlying act that was subject to internal review. According to this judgement, "the Court is not entitled to issue directions to the Commission, in the event of annulment of the decision on the request for internal review, or to effect the revocation of the authorization decision." 71 Nevertheless, the General Court, in this decision, added that arguments raised relating to the deficiencies in the authorization, "could have a bearing on the present action only if the Commission had, in the decision on the request for internal review, endorsed the elements contained in the application for authorization."72 It has accepted that "a party requesting the internal review of an administrative act adopted under environmental law is required to put forward any facts and evidence or any legal arguments raising serious doubts about the assessment made in that act by the EU institution or body," which means that a "party challenging a marketing authorization must therefore adduce substantial evidence liable to raise serious doubts as to the lawfulness of the grant of that authorization." ${ }^{73}$ The Commission is obliged to consider these elements. ${ }^{74}$

\footnotetext{
${ }^{66}$ See findings of the Compliance Committee, supra note 22.

${ }^{67}$ Case T-177/13, TestBioTech eV and Others v. European Comm'n, ECLI:EU:T:2016:736 (Dec. 15, 2016), http://curia. europa.eu/juris/liste.jsf?language $=$ en $\&$ num $=\mathrm{T}-177 / 13$.

${ }^{68}$ Case C-82/17P, TestBioTech eV and Others v. European Comm'n, ECLI:EU:C:2019:719 (Sept. 12, 2019), http://curia. europa.eu/juris/liste.jsf?language $=$ en $\&$ num $=\mathrm{C}-82 / 17 \% 2520 \mathrm{P}$.

${ }^{69}$ TestBioTech eV et al, Case C-82/17P at para. 39. Further on both TestBioTech sets of rulings, see Giulia Claudia Leonelli, GMO Authorisations and the Aarhus Regulation: Paving the Way for Precautionary GMO Governance?, 26 MAASTRICHT J. EUR. \& Comp. L. 505 (2019). See also, ECJ, Case T-12/17, Mellifera eV, Vereinigung für wesensgemäße Bienenhaltung v. European Comm'n, ECLI:EU:T:2018:616 (Sept. 27, 2018), para. 35, http://curia.europa.eu/juris/liste.jsf?language=en\&td=ALL\&num=T-12/17. This judgment was upheld by the Court of Justice in ECJ, Case C-784/18 P Mellifera eV, Vereinigung für wesensgemäße Bienenhaltung v. European Comm'n, ECLI:EU:C:2020:630 (Sept. 3, 2020), http://curia.europa.eu/juris/liste.jsf?num=C-784/18.

${ }^{70}$ ECJ, Case T-108/17, ClientEarth v. European Comm'n, ECLI:EU:T:2019:215 (Apr. 4, 2019), http://curia.europa.eu/juris/ liste.jsf?language $=\mathrm{en} \& \mathrm{td}=\mathrm{ALL} \& \mathrm{num}=\mathrm{T}-108 / 17$.

${ }^{71} I d$. at para. 30. See also, Mellifera eV, Vereinigung für wesensgemäße Bienenhaltung, Case T-12/17 at para. 33.

${ }^{72}$ ClientEarth, Case T-108/17 at para. 54.

${ }^{73} \mathrm{Id}$. at para. 57.

${ }^{74} I d$. at para. 58.
} 
This means that the judicial control of internal review decisions may take into account arguments regarding the substantive unlawfulness of the underlying act to the extent that they were raised and substantiated in the request for internal review. Once again, the focus of the Court remains solely on the internal review decision, meaning that the possibility of control of the underlying act remains narrow. Yet, this case seems to go a step further than the TestBioTech case, showing a possible way to obtain such control, namely questioning the substantive legality of the act first before the Commission, obtaining a decision on the errors in the authorization identified in the request for internal review, and finally requesting the Court to control this decision. An appeal on this case is currently pending before the Court of Justice $^{75}$ regarding, among other things, the burden imposed on NGOs in demonstrating such substantive unlawfulness.

This effectively means that NGOs wishing to challenge the legality of the initial GMO authorization can only bring an action for annulment against that act under Article 263(4) TFEU. Nonetheless, according to the Plaumann interpretation of individual concern, which the Court held applicable equally to environmental litigation, ${ }^{76}$ and despite the warnings given by the Compliance Committee, ${ }^{77}$ they are unlikely to be granted standing. As a consequence, environmental NGOs will likely not be able to challenge the Commission Implementing Decision concluding the authorization process.

\section{Interim Conclusions}

The analysis carried out above shows that a number of grey areas of judicial review are present with respect to the composite procedure set out in Regulation No. 1829/2003. They relate, first, to the actions and opinions of the national competent authorities. While the recent case law of the Court of Justice seems to point towards the jurisdiction of the European level to review also the national parts of the procedure, it is not clear what the extent of this review will be and whether violations of national law will remain immune from judicial control.

Furthermore, while EFSA's opinion will be challengeable in an annulment action together with the final Commission Implementing Decision, standing issues might arise for third parties because of the restrictive notion of individual concern set in the CJEU's case law. Also, NGOs will face similar hurdles should they want to challenge the final act of the decision-making process, with the internal review procedure only providing for a limited alternative. With respect to this second aspect, issues regarding compliance not only with Article 47 of the Charter but also with the Aarhus Convention can be identified.

\footnotetext{
${ }^{75}$ ECJ, Case C-458/19P ClientEarth v. Comm'n [pending], https://curia.europa.eu/juris/liste.jsf?oqp $=\& f o r=\& m a t=o r \&$ jge $=\& \mathrm{td}=\% 3 \mathrm{BALL} \&$ jur $=\mathrm{C} \% 2 \mathrm{CT} \% 2 \mathrm{CF} \&$ num $=\mathrm{C}-458 \% 252 \mathrm{~F} 19 \mathrm{P} \& \mathrm{page}=1 \&$ dates $=\& \mathrm{pcs}=$ Oor $\& \lg =\& \mathrm{pro}=\& \mathrm{mat}=\mathrm{or} \& \mathrm{cit}=$ none $\% 252$ CC $\% 252$ CCJ $\% 252$ CR $\% 252 \mathrm{C} 2008 \mathrm{E} \% 252 \mathrm{C} \% 252 \mathrm{C} \% 252 \mathrm{C} \% 252 \mathrm{C} \% 252 \mathrm{C} \% 252 \mathrm{C} \% 252 \mathrm{C} \% 252 \mathrm{C} \% 252 \mathrm{C} \% 252 \mathrm{Ctrue} \%$ $252 \mathrm{Cfalse} \% 252 \mathrm{Cfalse} \&$ language $=$ en $\&$ avg $=\& \mathrm{cid}=1477834$.

${ }^{76}$ ECJ, Case T-585/93, Stichting Greenpeace Council (Greenpeace International) and others v. Comm'n of the European Cmtys., ECLI:EU:T:1995:147 (Aug. 9, 1995), paras. 18-19, http://curia.europa.eu/juris/liste.jsf;jsessionid= 9ea7d2dc30d647f1ec0c433b4a4f8666fea3420a5f8f.e34KaxiLc3qMb40Rch0SaxyMahr0?num=T-585/93.

${ }^{77}$ See the Findings of the Aarhus Convention Compliance Committee on Communication ACCC/C/2008/32, supra note 22. Within the Aarhus Convention system, communications may be brought before the Committee by one or more members of the public concerning any Party's compliance with the Convention. This Communication was submitted to the Compliance Committee the non-governmental organization (NGO) ClientEarth, the communicant, and was supported by a number entities and a private individual. In the Communication, the communicant alleged that the European Union was in violation of several access to justice-related article of the Aarhus Convention.
} 


\section{GMOs Decision-Making Procedures in Directive 2001/18/EC and Access to Justice \\ I. The Authorization Procedure Under Directive 2001/18/EC: A Mixed Procedure with Strong Deliberative Elements}

Directive 2001/18/EC establishes the authorization procedure for the deliberate release into the environment of GMOs for uses other than food and feed. ${ }^{78}$ The procedure for placing on the market of GMOs as or in products ${ }^{79}$ has two stages: One national and one supranational. It may be thus considered as a true "composite" or "mixed" procedure. ${ }^{80}$

The procedure starts in the national stage through the submission of a notification to the competent authority of the Member State where the GMO is placed on the market for the first time. ${ }^{81}$ The notification in this case constitutes an application for authorization because the notifier may only place the product on the market once it has received the written consent of the competent authority and in accordance with all the conditions laid down in that authorization. ${ }^{82}$ It is the duty of the competent authority to verify "without delay" if the notification complies with the conditions laid down and, if necessary, request additional information from the notifier. ${ }^{83}$ Part of the information must be notified "immediately" to the competent authorities of the other Member States and to the Commission. ${ }^{84}$

After verification that the notification contains all the elements required by the directive, the competent authority shall forward a copy of the notification to the Commission which shall forward it in turn to the competent authorities of the other Member States within 30 days of its receipt. ${ }^{85}$ In this stage, the Commission also immediately makes available to the public the summary referred to in Article 13(2)(h) ${ }^{86}$ allowing the public to make comments to the Commission within thirty days, which are to be immediately forwarded to the competent authorities. ${ }^{87}$

Then the competent authority examines the compliance of the notification with the directive to assess the possibility of indication that the GMOs in question should be placed on the market, after assessing whether the release risk to human health and the environment. The national stage ends with the preparation of an assessment report in accordance with the guidelines set out in Annex VI of the directive, which shall be sent to the notifier. This report may conclude for the existence of compliance, whether conditional or not, or non-conformity of the notification with the directive. ${ }^{88}$ The report must be sent to the Commission together with the information on which it is based and shall be sent by the Commission to the competent authorities of the other Member States. ${ }^{89}$

After analyzing the report, the Commission or any competent authority may request additional information, make comments or present reasoned objections to the placing on the market of GMOs. $^{90}$ Reasoned comments or objections and their replies should be sent to the

\footnotetext{
${ }^{78}$ The CJEU has considered that also organisms obtained by means of techniques/methods of mutagenesis constitute genetically modified organisms. See ECJ, Case C-528/16, Confédération paysanne and Others v. Premier Ministre and Ministre de l'agriculture, de l'agroalimentaire et de la forêt, ECLI:EU:C:2018:583 (July 25, 2018), http://curia.europa.eu/juris/liste.jsf? language $=$ en\&td $=$ ALL\&num $=$ C-528/16.

${ }^{79}$ There is a different procedure for the deliberate release of GMOs for any other purpose than for placing on the market in Articles 5 to 11 of the Council Directive.

${ }^{80} \mathrm{Cf}$. Giacinto Della Cananea, The European Union's Mixed Administrative Proceedings, 68 L. \& ConTEMP. Probs. 197, 205 (2004). See Keessen, supra note 28, at 31.; Brosset, supra note 8, at 555.

${ }^{81}$ Council Directive 2001/18, supra note 4, at art. 13(1), para 1 . See Keessen, supra note 28, at 32-33.

${ }^{82}$ Council Directive 2001/18, supra note 4, at art. 19(1-2).

${ }^{83} I d$. at art. 13(1), para. $2 \&(2)$

${ }^{84} I d$. at art. 13(1), para. 1.

${ }^{85} I d$. at art. 13(1), para. 3.

${ }^{86}$ If they are not considered confidential under Article 25 of the directive.

${ }^{87}$ Council Directive 2001/18, supra note 4, at art. 24(1).

${ }^{88} I d$. at art. $14(1-3)$.

${ }^{89} I d$. at art. $14(2) 2^{\text {nd }}$ indent \& para. 2.

${ }^{90}$ Id. at art. 15(1).
} 
Commission, which shall distribute them immediately to all competent authorities. In this case, the competent authorities and the Commission may discuss any outstanding issues-especially an objection-with the aim of arriving at an agreement. If the assessment report indicates that the GMO in question should be placed on the market, the Commission also makes it available to the public, allowing it to make comments to the Commission within thirty days. ${ }^{91}$ The Commission immediately forwards the comments to the competent authorities.

As a result of this deliberative stage, several hypotheses are possible: ${ }^{22}$

1) If the competent authority which prepared the report decides that the product may be placed on the market, in the absence of reasoned objections by a Member State or the Commission, or if the outstanding issues have been resolved (that is, in case of an agreement), it shall give written consent for placing the product on the market. The national decision is communicated to the notifier and the other Member States and the Commission are informed thereof. ${ }^{93}$ In this case, which rarely occurs in practice, we have a national decision which produces automatic effects throughout the EU-Article 19 (1) and Article 22 of the directive-a typical example of a transnational administrative act. ${ }^{94}$ The decision may impose specific conditions on certain ecosystems or geographic areas, which means, for example, that the effects of this decision may vary from Member State to Member State. ${ }^{95}$

2) If the competent authority which has drawn up the report concluding that the GMO should not be placed on the market maintains this conclusion, the notification shall be refused by a reasoned national decision. ${ }^{96}$ In this case, the existence of disagreement with other Member States or the Commission does not prevent the exercise of the decisionmaking power of the Member State.

3) If a competent authority other than the one which prepared the report or the Commission maintains an objection to the placing on the market of the product, the Commission, through a comitology examination procedure, will gain the decision-making power. ${ }^{97}$ This means that the Committee set up under Article 30 of the Directive 2001/18/EC has the possibility to approve or reject the draft decision ${ }^{98}$ by a qualified majority vote, which is binding to the Commission. If there is no qualified majority either for or against the proposed act, the Commission must submit a new, amended version to the same Committee or to the Appeal Committee. If the Appeal Committee gives no opinion,

\footnotetext{
${ }^{91} I d$. at art. 24(1).

${ }^{92} \mathrm{Id}$. at arts. $15 \& 18$.

${ }^{93}$ Council Directive 2001/18, supra note 4, at art. 15(3). In its judgment in Greenpeace France, the CJEU already had the opportunity to decide, with regard to Directive 90/220, which preceded Directive 2001/18/EC, that, if after sending the application for the placing on the market of a GMO to the Commission no objections are raised by Member State or the Commission, the competent authority which transmitted the application with an assent to the Commission is required to grant "written consent" which allows the product to be placed on the market is bound to decide accordingly. However, if, in the meantime, the Member State concerned has new information which would lead it to consider that the product covered by the notification may present a risk to human health and the environment, it may reject the request, if it informs the Commission and the other Member States immediately. ECJ, Case C-6/99, Association Greenpeace France and Others v. Ministère de l'Agriculture et de la Pêche and Others, ECLI:EU:C:2000:148 (Mar. 21, 2000), para. 47, http://curia.europa.eu/ juris/liste.jsf?language $=$ en\&num=C-6/99. See Thomas Von Danwitz, EuropäIsches Verwaltungsrecht 629 (2008); Keessen, supra note 28, at 37.

${ }^{94}$ See Chevalier \& Dubos, supra note 17 , in this issue.

${ }^{95}$ See Keessen, supra note 28 , at 37.

${ }^{96}$ Council Directive 2001/18, supra note 4, at art. 15(2).

${ }^{97}$ Council Directive 2001/18, supra note 4, at arts. 18 \& 30. To the extent that Article 30(2) of the directive refers to Article 5 of the Comitology Decision II, which was repealed, it must be understood to refer to the examination procedure and it must be considered that the basic act provides that, in the absence of an opinion, the Commission may not adopt the draft implementing act. See Comitology Regulation, supra note 37, at art. 5(4), para. 2(b), ex vi art. 13(1)(c).

${ }^{98} C f$. Hungary v. Comm'n, Case T-240/10 at para. 111.
} 
the Commission can adopt the decision, which takes the form of an Implementing Decision and is addressed to the Member State which received the notification. If that decision is favorable, the competent authority which produced the assessment report issues a written authorization for the placing on the market or renewal of the authorization by notifying the notifier and informing the other Member States and the Commission. ${ }^{99}$ The directive is not clear on what should happen if the decision is not favorable. In that case it would be logical if the Implementing Decision rejecting the notification was addressed to the notifier because, in that case, the directive does not establish any further acts by the competent authorities. ${ }^{100}$

Thus, the impossibility of obtaining consensus - in other words, of finding a satisfactory answer for all the actors through cooperation-bears the consequence of transferring the competence for the decision on which interest should prevail to the Commission. It intervenes after a stage of the procedure in which the Commission itself or one of the national authorities raised objections and an agreement was not possible. The authorization procedure foresees, therefore, a conditional supranational stage, because this stage is only necessary after raising one or more objections and the impossibility to find an agreement. This means that ultimately the Commission has the power to claim the decision-making power by raising an objection. Nonetheless, Member States continue to be able to exercise their own discretion through participation in the comitology procedure, another cooperation instrument. Formally, however, the majority of the scenarios end with the emergence of a transnational act by the national authorities, except for the case of the rejection of the notification by the Commission.

The one foreseen by the directive is also a procedure based on cooperation between the Member States and the Commission-where the decision-making power lies primarily with the Member States. The procedure is fundamentally non-hierarchical, horizontal, with the possibility to recourse to mediation, and agreement between national authorities in the event of disagreement. ${ }^{101}$ In practice, however, the cooperation often does not occur, leading to situations of blockage of the decision-making procedure. ${ }^{102}$ In those cases, the possibility of judicial review is ever more important.

The table below schematizes the various steps of the decision-making process and the relevant institutional actors.

\footnotetext{
${ }^{99}$ Council Directive 2001/18, supra note 4 , at art. $18(2)$.

${ }^{100}$ This is a noticeable difference with respect to the procedure for the authorization of pharmaceuticals, in which the EU level part of the process is always concluded with a Commission decision addressed to the Member States. Röttger-Wirtz \& Eliantonio, supra note 11, at 401.

${ }^{101}$ Cf. Sabino Cassese, European Administrative Proceedings, 68 L. \& ConTEMP. Probs. 21, 29 (2004); Claudio Franchini, European Principles Governing National Administrative Proceedings, 68 L. \& ConTEMP. ProBs. 183, 191 (2004). See VoN DANwiTZ, supra note 93, at 628-31; Della Cananea, supra note 80, at 205.

${ }^{102}$ One example of this blockage is the application for an authorization for the placing on the Spanish market of "maize 1507." In this case, after there was no qualified majority either for or against the Commission's proposal and no further steps were taken, the applicant filed an action for omission against the Commission-which was judged in its favour. See ECJ, Case T-164/10, Pioneer Hi-Bred International, Inc. v. European Comm'n, ECLI:EU:T:2013:503 (Sept. 26, 2013), http://curia. europa.eu/juris/liste.jsf?num=T-164/10. Furthermore, even if a decision is actually reached, the Member States may opt out on a later stage. The opt-out clause was introduced as the new Article 26b of Directive 2001/18/EC, inserted by Directive (EU) 2015/412 of the European Parliament and of the Council of 11 March 2015. It allows individual Member States to restrict or prohibit GMO cultivation on their territory-or part of it-provided that such measures are justified on the basis of compelling reasons under certain conditions-even after the use of GMO was been authorized. See Directive 2015/412 of the European Parliament and of the Council of 11 March 2015 Amending Directive 2001/18/EC as Regards the Possibility for the Member States to Restrict or Prohibit the Cultivation of Genetically Modified Organisms (GMOs) in Their Territory, 2015 O.J. (L 68) 1.
} 
Table 2. Steps of the decision-making process established by Directive 2001/18/EC

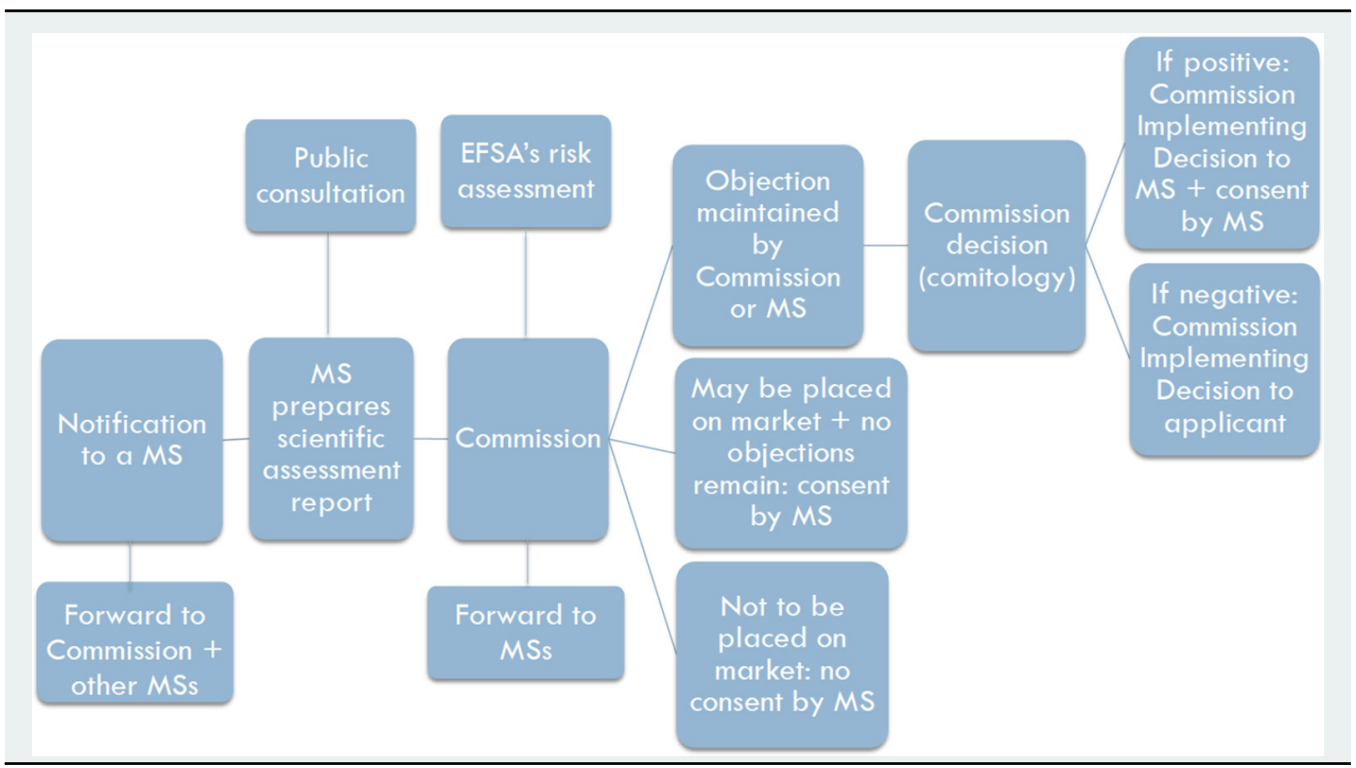

\section{The Gaps of Judicial Protection: The Uncertain Application of the Berlioz Ruling and the Magic of the Preliminary Question of Validity}

With respect to the procedure examined above, the following gaps of judicial protection can be highlighted.

In the scenarios described under one and two, the final word in the procedures rest with the national level-with the competent authority either granting scenario one or rejecting scenario two-consent by an act of the Member State in question. In both those cases, access to justice will be ensured, prima facie, by national law. This means that it would be up to the national level to ensure compliance with access to justice rules in compliance with the Aarhus Convention. In any case, a possible challenge by the authorization holder, a competitor or NGO on the basis of the scientific assessment report by the Member State will occur together with the final decision. In this respect, no gaps of judicial protection seem to be present.

With respect to a possible challenge of the objections made both by Member States and the Commission, matters become more complex because these would constitute preparatory acts in the decision-making, whereby neither the Borelli case law-because of the discretionary nature of the actions of the competent national authorities-nor the Berlusconi case lawbecause of the structure of the procedure culminating with a national decision-seem to be clearly applicable. As regards a possible objection of the Commission, a direct action under Article 263 TFEU seems unlikely because of the preparatory nature of the measure at stake, unable to infringe the applicant's legal sphere. ${ }^{103}$ At the same time, it might be thinkable that, before the national court, an applicant might ask for a preliminary question of validity of the act containing the objection to be sent to the Court of Justice under Article 267 TFEU. The latter procedure, as held by the Court itself, is open to all acts of the EU institutions, including

\footnotetext{
${ }^{103}$ ECJ, Case 60/81, IBM Corporation v. Comm'n of the European Cmtys., ECLI:EU:C:1981:264 (Nov. 11, 2981), http:// curia.europa.eu/juris/liste.jsf?language $=$ en $\&$ jur $=C, T, F \& n u m=60 / 81$.
} 
preparatory ones. ${ }^{104} \mathrm{~W}$ ith respect instead to objections raised by other Member States, and in light of inapplicability of the Borelli case law, a direct challenge before the courts of the authority making the objection is likely going to be held inadmissible because of the preparatory nature of the measure. A solution to this gap of judicial protection might be found in the Berlioz case law, in which the CJEU has held that a national court is able to review the lawfulness of acts taken by foreign authorities in order to comply with Article 47 of the Charter. ${ }^{105}$ In application of this case law, therefore, the national court where the action against the final measure is brought might be able to review the unlawfulness of possible objections raised by foreign national authorities, using the EU law as a parameter.

The success of a direct or indirect challenge by a competitor or NGO on the basis of non-objection by a Member State or the Commission is unlikely because it would depend on the recognition that these actors are under a duty to act. In the case of a non-objection by the Commission, it is likely that the Court would decide that the Commission is operating within its margin of discretion, outside of the possibility of judicial control for its inaction under Article 265 TFEU. Pursuant to this provision, the EU courts may review failures to address to the applicant any act other than a recommendation or an opinion. Despite this broad formulation, however, the EU courts have held that failures to act can only be challenged when an EU institution is under a clear obligation to act, which is not the case in the content of the procedure at stake. ${ }^{106}$

In the scenario described in three, the regime applicable to access to justice is even more complex because of the intervention of the Commission as the main driver of the decision-making procedure. In that scenario, given that an objection by a Member State or the Commission is maintained, it is for the Commission to decide on the request through a comitology examination procedure before the Committee established under Article 30(1) of Directive 2001/18/EC.

In case of rejection of the notification by a Commission Implementing Decision, which is addressed to the notifier, as there are no further national steps, a challenge by the applicant is admissible before the CJEU without any hurdles. The same can be said if the Commission fails to present a draft decision to the Committee. ${ }^{107}$

If the Commission's Implementing Decision is favorable to the notifier, it is for the national competent authority that produced the assessment report to issue the written authorization for the placing on the market or renewal of the authorization. ${ }^{108}$ The Commission's Implementing Decision, in this case, is addressed to the Member State of the competent authority that produced the assessment report and binds that authority. In this situation, the notifier, as well as competitors or NGOs, may wish to challenge the authorization because of the conditions it imposes. In that case, access to justice lies primarily before the national courts and the only way to challenge the legality of the consent by the Commission is for the national court to refer a preliminary question of validity to the CJEU, under the Fotofrost case law. ${ }^{109}$ Also in respect to such cases, there is no "gap" of judicial protection.

\footnotetext{
${ }^{104}$ ECJ, Case C-521/04, Hans-Martin Tillack v. Comm'n of the European Cmtys., ECLI:EU:C:2005:240 (Apr. 19, 2005), http://curia.europa.eu/juris/liste.jsf?language=en\&num=C-521/04. See also, Case C-322/88, Grimaldi v. Fonds des maladies professionnelles, ECLI:EU:C:1989:646 (Dec. 13, 1989), para. 8, http://curia.europa.eu/juris/liste.jsf?language=en\&jur=C,T,F\& num $=322 / 88$.

${ }^{105}$ Berlioz Investment Fund SA, Case C-682/15.

${ }^{106}$ ECJ, Case T-95/96, Gestevisión Telecinco v. Comm'n, ECLI:EU:T:1998:206 (Sept. 15, 1998), para. 71, http://curia.europa. eu/juris/liste.jsf?language=en\&num=T-95/96; ECJ, Case T-127/98, UPS Europe v. Comm'n, ECLI:EU:T:1999:167 (Sept. 9, 1999), para. 34, http://curia.europa.eu/juris/liste.jsf?language=en\&num=T-127/98.

${ }^{107} \mathrm{An}$ action for annulment is the possible avenue. See ECJ, Case T-164/10, Pioneer Hi-Bred International, Inc. v. European Comm'n, ECLI:EU:T:2013:503 (Sept. 9, 1999), http://curia.europa.eu/juris/liste.jsf?num=T-164/10.

${ }^{108}$ Council Directive 2001/18, supra note 4, at art. 18(2).

${ }^{109}$ ECJ, Case C-314/85, Foto-Frost v. Hauptzollamt Lübeck-Ost, ECLI:EU:C:1987:452 (Oct. 22, 1987), http://curia.europa. $\mathrm{eu} /$ juris/liste.jsf?language $=$ en $\&$ jur $=\mathrm{C}, \mathrm{T}, \mathrm{F} \&$ num $=314 / 85$.
} 


\section{Interim Conclusions}

The reflections made above show that, with respect to the composite decision-making process set out in Directive 2001/18/EC, judicial protection lies primarily with the national courts, as the concluding act of the decision-making process is a national decision. This setup presents several points of attention.

First, while the assessment report may be challenged together with the final authorization decision, issues may arise with respect to the national and EU objections. While with respect to the latter, as well as with respect to a challenge against the Commission Implementing Decision addressed to the Member States in the scenario three presented above, the preliminary reference procedure might fill possible gaps of judicial protection, national input will instead raise more concern. As direct challenges against national input will be unlikely, the only possible patch seems to apply the Berlioz case law. Yet, this ruling was rendered in the context of a mechanism of administrative cooperation and assistance in tax matters, a policy area and regulatory setup which is very different from the one under examination.

Furthermore, one significant difference between the procedure at stake and the one considered by the Court in Berlioz is that the mechanism of cooperation set up in the relevant EU legislation did not leave much margin of discretion to national authorities as to how to act in the process, while the participation of national authorities in the GMO authorization process and their raising of objections is left entirely to the discretion of the authorities themselves. This circumstance might justify a limited applicability of the Berlioz ruling in the context of GMO authorizations.

Finally, as mentioned above, and similarly to what has been concluded with respect to the Berlusconi ruling, the ruling in Berlioz only allows the judicial control of foreign acts against the parameters of EU law, leaving a significant gap of judicial protection with respect to the judicial control of violation of foreign national law.

\section{E. Conclusions}

The GMO authorization procedures set out in Regulation (EC) No. 1829/2003 and Directive 2001/ 18/EC represent a spectacular playground to observe the unfolding of vertical and horizontal composite procedures. They provide for various cooperation mechanisms, between the Commission, the European Food Safety Authority, and the competent national authorities. The procedures, albeit presenting significant differences in steps, have two clear common features, namely their basis on a risk assessment carried out by the EFSA, and the presence of various moments to preempt political or judicial confrontation, and provide incentives for consensus. These features result in a complex web of actions, opinions, objections, and decisions, which the regulatory framework only captures to some extent.

This complexity poses a challenge and a threat to the judicial control of the various steps of the procedure and to the compliance with Article 47 of the Charter of Fundamental Rights. While the recent case law of the Court of Justice in Berlusconi and Berlioz seems to move towards an increasingly more "holistic" control of these composite administrative procedures, several questions still remain open as to whether their scope encompasses all possible profiles of unlawfulness.

Furthermore, the limitations of judicial review-especially at the EU level-pose specific problems with respect to presence and relevance of the Aarhus Convention in this policy area. While the current Commission proposal amending the Aarhus Regulation seems to fill the gaps highlighted by the Compliance Committee only to a limited extent, it will be up to the Court of Justice to ensure compliance with, at least, Article 47 of the Charter.

Cite this article: Lanceiro R, Eliantonio M (2021). The Genetically Modified Organisms' Regime: A Playground for MultiLevel Administration and a Nightmare for Effective Judicial Protection?. German Law Journal 22, 371-390. https://doi.org/ 10.1017/glj.2021.16 